\title{
Pengembangan LKPD Interaktif Berbasis React Materi Pecahan pada Siswa Kelas 4 SD
}

\author{
Yuli Rahmadani, Yuniawatika*, Lilik Bintartik \\ Universitas Negeri Malang, Jl. Semarang No. 5 Malang, Jawa Timur, Indonesia \\ *Penulis korespondensi, Surel: yuniawatika.fip@um.ac.id
}

Paper received: 28-9-2021; revised: 12-10-2021; accepted: 19-10-2021

\begin{abstract}
The purpose of this study is to produce interactive worksheets based on REACT valid fraction material according to material experts, media experts, practitioners and practically according to students. This study uses a research model for developing Dick and Carey. Based on the results of the study, interactive worksheets are very valid according to material experts and practitioners with a percentage of 94.9 percent, very valid according to media experts and practitioners with a percentage of 94.2 percent, and very practical according to users with 88.5 percent. From the percentage obtained, the product can be used without revision.
\end{abstract}

Keywords: interactive worksheets; REACT; fraction

\begin{abstract}
Abstrak
Tujuan dari penelitian ini adalah menghasilkan LKPD interaktif berbasis REACT materi pecahan yang valid menurut ahli materi, ahli media, praktisi dan praktis menurut siswa. Penelitian ini menggunakan model penelitian pengembangan Dick dan Carey. Berdasarkan hasil penelitian LKS interaktif sangat valid menurut ahli dan praktisi materi dengan persentase 94,9 persen, sangat valid menurut ahli dan praktisi media dengan persentase 94,2 persen, dan sangat praktis menurut pengguna dengan 88,5 persen. persentase. Dari prosentase yang diperoleh, produk dapat digunakan tanpa revisi.
\end{abstract}

Kata kunci: LKPD; REACT; pecahan

\section{Pendahuluan}

Kegiatan pembelajaran yang ideal adalah kegiatan yang harus melibatkan peserta didik aktif dalam proses pembelajaran. Salah satu cara yang dapat dilakukan yaitu dengan memberikan Lembar Kerja Peserta Didik (LKPD). LKPD menurut Majid (2012) berupa lembaran-lembaran berisi tugas yang harus dikerjakan peserta didik, dilengkapi dengan petunjuk mengerjakan tugas dan petunjuk melakukan kegiatan. Sedangkan menurut Depdiknas (2008) LKPD adalah lembaran-lembaran berisi tugas yang harus dikerjakan oleh peserta didik. Lembar kegiatan biasanya berupa petunjuk, langkah-langkah untuk menyelesaikan suatu tugas. Keuntungan menggunakan LKPD adalah memudahkan pendidik dalam melaksanakan pembelajaran, bagi peserta didik akan belajar mandiri dan belajar memahami serta menjalankan suatu tugas tertulis. LKPD menurut Darmadjo \& Kaligis (dalam Rohaeti dkk, 2009) harus memuat syarat didaktis, syarat konstruk, dan syarat teknis.

Hasil wawancara dengan guru mata pelajaran Matematika Kelas 4, guru sering menggunakan LKPD untuk melatih peserta didik aktif dalam menemukan dan memahami materi pelajaran. Berdasarkan pengamatan terhadap LKPD yang digunakan oleh guru, terdapat beberapa masalah pada LKPD materi pecahan yaitu unsur-unsurnya tidak lengkap, hanya memuat kompetensi dasar, soal-soal, dan petunjuk mengerjakan soal. LKPD harus memuat unsur-unsur meliputi (1) judul, (2) petunjuk belajar, (3) kompetensi yang akan 
dicapai, (4) indikator, (5) informasi pendukung dan langkah kerja, (6) tugas-tugas, dan (7) penilaian (Depdiknas, 2006). Selain itu, LKPD yang digunakan kurang memuat syarat didaktis dikarenakan soal-soal tidak berurutan, sehingga peserta didik kurang bisa menemukan konsep. Selain itu, LKPD kurang memenuhi syarat teknis dikarenakan tidak ada gambar sama sekali. Penampilan LKPD juga membosankan karena berisi soal-soal, tidak dikombinasi dengan gambar. Seharusnya, LKPD sebagai media pembelajaran harus memuat gambar. Menurut Gagne (dalam Sadiman, dkk, 2007) media memiliki beberapa macam komponen atau segala alat fisik yang dapat merangsang peserta didik untuk belajar. Salah satu jenis media adalah visual yaitu media yang dapat dilihat seperti media gambar. Media gambar adalah media visual berbentuk grafis yang mengkombinasikan kenyataan dan gagasan secara kuat dan jelas melalui kombinasi tersebut (Sudjana, 2007). Sehingga, materi ataupun soal pada LKPD harus memuat gambar karena peserta didik akan lebih memahami suatu materi atau soal jika dilengkapi dengan gambar terutama gambar yang diketahui peserta didik.

Pada saat kegiatan pembelajaran menggunakan LKPD, guru menggunakan metode diskusi dengan cara mengelompokkan untuk merangsang interaksi peserta didik agar aktif bekerja sama. Menurut Bapak Endrik, peserta didik lebih senang belajar bersama kelompok daripada belajar menggunakan metode konvensional karena dianggap membosankan. Namun, pada saat bekerja kelompok, peserta didik kesulitan dalam mengemukakan pendapatnya. Hal ini dikarenakan peserta didik kurang percaya diri sehingga ketika disuruh mengemukakan pendapatnya cenderung diam.

Kelas 4 SD Lab Kota Blitar sering memanfaatkan teknologi dalam kegiatan pembelajaran termasuk pembelajaran matematika. Peserta didik sangat antusias ketika belajar dengan memanfaatkan teknologi. Namun, guru belum pernah menggunakan LKPD interaktif yang biasanya memanfaatkan teknologi. Multimedia interaktif (interactive multimedia) menurut Sutopo (2003) adalah multimedia yang memerlukan keterlibatan aktif penggunanya, karena pengguna dapat memilih apa saja yang akan dilakukan selanjutnya, mendapatkan jawaban yang akan mempengaruhi komputer untuk menjalankan fungsi selanjutnya sesuai dengan bahasa pemrograman yang dipilih pengguna. Keterlibatan aktif peserta didik akan menambah antusias ketika belajar.

Berdasarkan permasalahan yang disebutkan, maka perlu dikembangkan LKPD interaktif yang sesuai dengan syarat penyusunan LKPD, dapat mendorong partisipasi aktif peserta didik, dan membantu pemahaman peserta didik yaitu LKPD berbasis REACT. LKPD berbasis REACT menurut Yuniawatika (2011) terdiri dari lima tahap antara lain, relating (mengaitkan), experiencing (mengalami), applying (menerapkan), cooperating (bekerjasama), dan transferring (mentransfer). Perlunya dikembangkan LKPD berbasis REACT karena dapat membantu peserta didik untuk menemukan dan menerapkan konsep materi yang dipelajari melalui aktivitas dan soal-soal yang dikaitkan dengan kehidupan sehari-hari. Tahap-tahap pada LKPD berbasis REACT dikerjakan secara berkelompok yang sesuai dengan karakteristik peserta didik kelas 4 SD Lab Kota Blitar. Peserta didik lebih antusias jika pembelajaran menggunakan teknologi sehingga perlu dikembangkan bahan ajar atau LKPD yang interaktif. Berdasarkan paparan di atas, perlu dikembangkan Lembar Kerja Peserta Didik (LKPD) Interaktif Berbasis REACT materi Pecahan pada Peserta didik Kelas 4 SD LAB UM Kota Blitar.

Berdasarkan paparan di atas, peneliti tujuan antara lain: (1) Menghasilkan LKPD Interaktif Berbasis REACT materi pecahan untuk peserta didik kelas 4 yang valid menurut ahli 
materi dan praktisi; (2) Menghasilkan produk LKPD Interaktif Berbasis REACT materi pecahan untuk peserta didik kelas 4 yang valid menurut ahli media dan praktisi; (3) Menghasilkan produk LKPD Interaktif Berbasis REACT materi pecahan untuk peserta didik kelas 4 yang praktis menurut peserta didik sebagai pengguna.

\section{Metode}

LKPD interaktif berbasis REACT menggunakan model penelitian pengembangan Dick \& Carey. Tahap-tahap pada penelitian ini adalah: (1) analisis kebutuhan, (2) desain produk, (3) validasi evaluasi, dan (4) produk akhir. Tahap analisis kebutuhan meliputi analisis silabus, analisis KI \& KD kurikulum 2013, dan penetapan materi. Tahap desain produk meliputi produksi awal LKPD, pengembangan LKPD, menentukan komponen layout, judul, dan penyusunan instrumen penilaian. Tahap validasi evaluasi meliputi konsultasi awal, validasi, revisi produk, dan uji coba kepraktisan produk. Tahap terakhir yaitu produk akhir yang menghasilkan produk yang valid dan praktis, yang telah divalidasi oleh ahli materi, ahli media, praktisi, dan pengguna.

Subjek pada penelitian ini yaitu peserta didik kelas 4 SDN Kalimanis 4 untuk uji coba terbatas, peserta didik kelas 4 SD Lab UM untuk uji coba lapangan, guru matematika sebagai praktisi lapangan, ahli materi dan ahli media sebagai validator ahli. Jenis data yang digunakan yaitu data kualitatif dan kuantitatif. Data kuantitatif diperoleh dari validasi materi, validasi media, dan validasi pengguna. Validasi materi dan validasi media menilai tingkat kevalidan produk. Validasi materi dilakukan oleh ahli materi dan praktisi lapangan. Sedangkan validasi media dilakukan oleh ahli media dan praktisi lapangan. Validasi pengguna menilai tingkat kepraktisan produk yang dilakukan peserta didik melalui uji coba. Data kualitatif diperoleh dari hasil wawancara guru matematika kelas 4 SD Lab, serta data hasil identifikasi instrumen berupa saran dan masukan dari ahli materi, ahli media, dan praktisi. Instrumen yang digunakan berupa pedoman wawancara, instrumen validasi materi, instrumen validasi media, instrumen kepraktisan yaitu angket peserta didik. Instrumen-instrumen dikumpulkan dan dianalisis menggunakan statistik deskriptif kualitatif.

\section{Hasil dan Pembahasan}

Data yang dihasilkan dari penelitian ini ada tiga yaitu, data hasil validasi materi, media, dan pengguna. Berikut adalah tabel hasil validasi materi yang dilakukan oleh ahli materi dan praktisi lapangan.

Tabel 1. Hasil Validasi Materi

\begin{tabular}{|c|c|c|c|c|}
\hline \multirow{2}{*}{ No. } & \multirow{2}{*}{ Aspek } & \multicolumn{2}{|c|}{ Skor } & \multirow[t]{2}{*}{ Rata-rata } \\
\hline & & Ahli Materi & Praktisi Lapangan & \\
\hline \multicolumn{5}{|c|}{ Materi } \\
\hline 1. & Ruang lingkup & 12 & 12 & 12 \\
\hline 2. & Keruntutan & 11 & 10 & 10,5 \\
\hline & Cakupan & 12 & 11 & 11,5 \\
\hline \multicolumn{5}{|c|}{ Keterlaksanaan REACT } \\
\hline 1. & Relating & 8 & 8 & 8 \\
\hline 2. & Experiencing & 7 & 7 & 7 \\
\hline 3 & Applying & 7 & 7 & 7 \\
\hline 4. & Cooperating & 8 & 8 & 8 \\
\hline 5. & Transferring & 8 & 8 & 8 \\
\hline \multicolumn{5}{|c|}{ Bahasa } \\
\hline 1. & Bahasa & 12 & 11 & 11,5 \\
\hline
\end{tabular}




\begin{tabular}{|c|c|c|c|}
\hline \multirow{2}{*}{ No. } & \multicolumn{2}{|c|}{ Skor } & \multirow[t]{2}{*}{ Rata-rata } \\
\hline & Ahli Materi & Praktisi Lapangan & \\
\hline Total skor & 85 & 82 & 83,5 \\
\hline Skor maksimal & 88 & 88 & 88 \\
\hline Persentase & $96,6 \%$ & $93,2 \%$ & $94,9 \%$ \\
\hline Kriteria & Sangat valid & Sangat valid & Sangat valid \\
\hline
\end{tabular}

Berdasarkan tabel di atas, persentase yang didapatkan dari penilaian validator ahli materi sebesar 96,6\%, validator praktisi lapangan sebesar 93,2\%. Rata-rata persentase dari validator ahli materi dan validator praktisi lapangan adalah $94,9 \%$ yang dapat diinterpretasikan dengan kriteria sangat valid. Hasil ini menunjukkan bahwa LKPD interaktif berbasis REACT layak digunakan tanpa revisi. Disamping itu, data kualitatif yang diperoleh berupa saran-saran yang diberikan oleh validator dijadikan sebagai bahan evaluasi materi untuk menyempurnakan produk pengembangan LKPD interaktif berbasis REACT. penilaian kevalidan materi mendapatkan saran untuk perbaikan selanjutnya dari validator ahli media yaitu sebelum membuat LKPD harus menyusun Kompetensi Inti (KI), Kompetensi Dasar (KD), dan indikator. Menurut Depdiknas (2004), langkah awal dalam menganalisis kurikulum harus meliputi KI, KD, indikator, dan materi pelajaran. Penyusunan di atas berguna sebagai pedoman dalam membuat LKPD sehingga tidak keluar dari KI, KD, dan indikator. Selain itu, indikator yang disusun harus memuat pengetahuan dan keterampilan. Karena indikator sebagai dasar untuk menentukan kegiatan pembelajaran, merumuskan bentuk dan jenis penilaian yaitu dengan membuat soal. Jika kegiatan yang dilakukan terarah dan sesuai indikator, soal yang dibuat valid dengan menyesuaikan indikator, maka tujuan pembelajaran akan tercapai.

Tabel 2. Hasil Validasi Media

\begin{tabular}{|c|c|c|c|c|}
\hline No. & Aspek & Ahli Media & $\begin{array}{l}\text { Skor } \\
\text { Praktisi Lapangan }\end{array}$ & Rata-rata \\
\hline \multicolumn{5}{|c|}{ Bahasa } \\
\hline & Bahasa & 12 & 11 & 11,5 \\
\hline \multicolumn{5}{|c|}{ Penyajian } \\
\hline 1. & Tulisan & 11 & 12 & 11,5 \\
\hline 2. & Gambar & 12 & 12 & 12 \\
\hline 3. & Tampilan & 11 & 11 & 11 \\
\hline 4. & Ilustrasi & 10 & 11 & 10,5 \\
\hline \multicolumn{2}{|c|}{ Total skor } & 56 & 57 & 56,5 \\
\hline \multicolumn{2}{|c|}{ Skor maksimal } & 60 & 60 & 60 \\
\hline \multicolumn{2}{|c|}{ Persentase } & $93,3 \%$ & $95 \%$ & $94,2 \%$ \\
\hline \multicolumn{2}{|c|}{ Kriteria } & Sangat valid & Sangat valid & Sangat valid \\
\hline
\end{tabular}

Berdasarkan tabel di atas, persentase didapatkan dari penilaian validator ahli media sebesar 93,3\%, validator praktisi lapangan sebesar 95\%. Rata-rata persentase dari validasi ahli media dan validator praktisi lapangan adalah 94,2\% yang dapat diinterpretasikan dengan kriteria sangat valid. Hasil ini menunjukkan bahwa LKPD interaktif berbasis REACT layak digunakan tanpa revisi. Disamping itu, data kualitatif yang diperoleh berupa saran-saran yang diberikan oleh validator dijadikan sebagai bahan evaluasi penyajian produk pengembangan LKPD interaktif berbasis REACT. Penilaian kevalidan media mendapatkan beberapa saran dari validator ahli materi agar produk dapat mencapai sempurna, yaitu pada aspek tulisan, tampilan, dan ilustrasi. Pada aspek tulisan, masih banyak yang menabrak gambar, untuk itu 
perlu dibenahi kembali agar nyaman dilihat. Pada aspek tampilan, ada beberapa keterangan tombol yang kurang sesuai dan berdekatan dengan tulisan lain. Seharusnya tombol dapat dibuat lebih bagus dan keterangan tombol diletakkan di dalam tombol untuk meminimalisir kebingungan dan tafsiran ganda. Menurut Darmadjo \& Kaligis (dalam Rohaeti dkk, 2009), LKPD harus memuat syarat didaktis yaitu menggunakan struktur kalimat yang jelas dan tidak menimbulkan penafsiran ganda. Pada aspek ilustrasi, ada beberapa warna tulisan tidak kontras dengan background. Seharusnya warna tulisan kontras dengan background agar dapat terbaca. Selain itu, posisi tombol masih banyak yang berubah-ubah, sedangkan posisi tombol harus tetap untuk meminimalisir kesulitan. Sedangkan penilaian dari guru sebagai validator praktisi lapangan hampir sama, yang berbeda adalah pada LKPD hampir semua bahasa menggunakan EYD, karena ada beberapa bagian yang kalimatnya terlalu panjang. Menurut Darmadjo \& Kaligis (dalam Rohaeti dkk, 2009), LKPD harus memuat syarat didaktis yaitu menggunakan kalimat yang sederhana dan pendek.

Tabel 3. Hasil Penilaian Kepraktisan Uji Coba Terbatas

\begin{tabular}{|c|c|c|c|}
\hline No & Pertanyaan & Ya & Tidak \\
\hline 1. & Mudah digunakan & 4 & \\
\hline 2. & Kalimat mudah dipahami & 4 & \\
\hline 3. & LKPD menarik & 4 & \\
\hline 4. & Pecahan dikaitkan dengan kehidupan sehari-hari & 4 & \\
\hline 5. & Memahami materi bentuk-bentuk pecahan & 4 & \\
\hline 6. & Menyelesaikan soal-soal pada LKPD & 0 & 4 \\
\hline 7. & Senang bekerja kelompok & 4 & \\
\hline 8. & Mengerjakan soal pecahan yang lebih sulit & 3 & 1 \\
\hline 9. & Isi LKPD bermanfaat & 4 & \\
\hline 10. & Senang belajar menggunakan LKPD & 4 & \\
\hline \multicolumn{2}{|c|}{ Total skor } & 35 & 5 \\
\hline \multicolumn{2}{|c|}{ Skor maksimal } & 40 & 40 \\
\hline \multicolumn{2}{|c|}{ Persentase } & $87,5 \%$ & $12,5 \%$ \\
\hline \multicolumn{2}{|c|}{ Kriteria } & Sangat praktis & \\
\hline
\end{tabular}

Berdasarkan tabel di atas mengenai angket yang diisi oleh 4 siswa kelas 4 SDN Kalimanis 4 diperoleh persentase sebesar 87,5\%. Hasil yang didapatkan menunjukkan bahwa LKPD interaktif berbasis REACT layak digunakan dalam pembelajaran matematika kelas 4 SD.

Tabel 4. Hasil Penilaian Kepraktisan Uji Coba Lapangan

\begin{tabular}{clcc}
\hline No. & \multicolumn{1}{c}{ Pertanyaan } & Ya & Tidak \\
\hline 1. & Mudah digunakan & 26 & 1 \\
2. & Kalimat mudah dipahami & 26 & 1 \\
3. & LKPD menarik & 25 & 2 \\
4. & Pecahan dikaitkan dengan kehidupan sehari-hari & 22 & 5 \\
5. & Memahami materi bentuk-bentuk pecahan & 22 & 5 \\
6. & Menyelesaikan soal-soal pada LKPD & 25 & 2 \\
7. & Senang bekerja kelompok & 26 & 1 \\
8. & Mengerjakan soal pecahan yang lebih sulit & 15 & 12 \\
9. & Isi LKPD bermanfaat & 27 & 0 \\
10. & Senang belajar menggunakan LKPD & 25 & 2 \\
\hline Total skor & 239 & 31 \\
\hline Skor maksimal & 270 & 270 \\
\hline Persentase & $88,5 \%$ & $11,5 \%$ \\
\hline
\end{tabular}




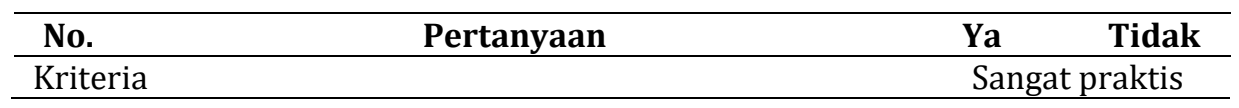

Berdasarkan tabel di atas mengenai angket yang diisi oleh 27 siswa kelas 4 SD Lab UM Kota Blitar diperoleh persentase sebesar 88,5\%. Hasil yang didapatkan menunjukkan bahwa LKPD interaktif berbasis REACT layak digunakan dalam pembelajaran matematika kelas 4 SD. Berdasarkan hasil refleksi dari uji coba yang dilakukan oleh peserta didik kelas 4 SD Laboratorium UM Kota Blitar, didapatkan beberapa temuan, yakni:

Peserta didik sangat antusias ketika belajar menggunakan teknologi. Hal ini dibuktikan dengan tertibnya proses pembelajaran saat peserta didik menggunakan LKPD interaktif berbasis REACT.

Peserta didik senang dan tertarik belajar materi bentuk-bentuk pecahan menggunakan LKPD interaktif berbasis REACT. Hal ini ditunjukkan dengan respon peserta didik ketika mengerjakan angket yaitu LKPD menarik karena terdapat lagu, gambar, dan animasi yang menambah semangat peserta didik ketika belajar.

Peserta didik mudah menggunakan LKPD interaktif berbasis REACT. Hal ini dibuktikan dengan respon peserta didik ketika mengerjakan angket yaitu LKPD mudah digunakan karena berisi petunjuk dan tombol-tombol. Selain itu, terdapat pertanyaan pengantar yang dihubungkan dengan kehidupan sehari-hari pada tahap relating di setiap aktivitas, sehingga dapat menimbulkan keingintahuan peserta didik terhadap materi.

Adanya interaksi antar peserta didik. Hal ini ditunjukkan dengan keterlibatan peserta didik yang saling bekerja sama, berdiskusi, dan saling membantu dalam mengerjakan soal-soal yang ada pada LKPD interaktif berbasis REACT.

Melalui penggunaan LKPD interaktif berbasis REACT, peserta didik banyak yang tertarik. Hal ini sejalan dengan pernyataan Smaldino, dkk (2014) bahwa multimedia interaktif adalah serangkaian alat pengantar pesan berupa teks, audio, dan gambar pada sebuah program komputer. Pada LKPD interaktif berbasis REACT, pembelajaran tidak hanya terfokus pada teks, namun menggunakan berbagai variasi media seperti audio dan gambar. Hal ini dapat meningkatkan minat dan ketertarikan peserta didik dalam proses pembelajaran. Pada LKPD interaktif berbasis REACT, terdapat petunjuk-petunjuk dan tombol yang memudahkan penggunaan. Sejalan dengan pernyataan Daryanto (2010) bahwa multimedia interaktif dilengkapi alat pengontrol yang dapat dioperasikan pengguna sehingga dapat menentukan apa yang akan dilakukan selanjutnya.

Berdasarkan penelitian terdahulu, LKPD berbasis REACT digunakan dalam pembelajaran Intani (2015) terbukti layak digunakan karena dilengkapi pertanyaan pengantar untuk menghubungkan dengan kehidupan sehari-hari, dan membuat pembelajaran menyenangkan karena berisi tampilan yang menarik. Hal ini sejalan dengan hasil temuan bahwa peserta didik antusias dalam mengerjakan LKPD karena berisi pertanyaan pengantar, dan tampilan LKPD yang menarik sehingga menambah motivasi belajar anak. Selain itu, adanya interaksi antar peserta didik dengan bekerja sama dan berdiskusi mengerjakan soal-soal pada LKPD interaktif berbasis REACT. Hal ini sejalan dengan Yuniawatika (2016) yaitu bahwa strategi REACT terdapat cooperating dimana pembelajaran dilakukan bersama kelompok 
untuk bekerja sama, sharing, merespon, dan berkomunikasi dengan pendidik lainnya. Selain itu, berdiskusi dengan teman yang lain adalah salah satu cara untuk mengasah keterampilan peserta didik yaitu berkomunikasi.

\section{Simpulan}

Berdasarkan hasil penelitian dan pembahasan dapat disimpulkan bahwa penelitian dan pengembangan ini menghasilkan produk berupa LKPD interaktif berbasis REACT materi bentuk-bentuk pecahan kelas 4 di SD Laboratorium UM Kota Blitar yang valid dan praktis. Berdasarkan validasi ahli materi, dapat diketahui bahwa validitas materi sebesar 94,9\% yang masuk kriteria sangat valid. Berdasarkan validasi ahli media, dapat diketahui bahwa validitas media sebesar 94,2\% yang masuk kriteria sangat valid. Berdasarkan validasi pengguna, dapat diketahui bahwa kepraktisan pengguna sebesar 88,5\% yang masuk kriteria sangat praktis. Dari persentase yang didapatkan, maka produk dapat digunakan tanpa revisi.

Saran-saran yang diajukan meliputi (1) saran pemanfaatan yaitu sebelum menggunakan LKPD interaktif berbasis REACT, ada beberapa hal yang harus dikuasai dan dipersiapkan, yaitu guru harus menguasai materi bentuk-bentuk pecahan agar dapat membantu peserta didik yang kesulitan, guru harus menguasai pengetahuan dasar komputer agar dapat mengoperasikan komputer, guru harus menguasai LKPD interaktif berbasis REACT materi pecahan terlebih dahulu agar dapat membantu peserta didik ketika mengalami kesulitan, peserta didik harus menguasai konsep dasar pecahan, perkalian, dan pembagian agar lebih mudah mengerjakan LKPD interaktif berbasis REACT materi pecahan, peserta didik dan guru harus menyiapkan laptop, charger laptop, headset untuk memudahkan penggunaan LKPD interaktif berbasis REACT materi pecahan, (2) saran diseminasi yaitu LKPD interaktif berbasis REACT sebaiknya dapat digunakan pada lingkup pendidikan yang lebih luas dengan mengevaluasi terlebih dahulu dengan menyesuaikan situasi dan kondisi sasaran yang dituju. Sebelum menggunakan produk LKPD interaktif berbasis REACT materi pecahan, sebaiknya dilakukan sosialisasi pelatihan cara mengoperasikan produk agar memudahkan penggunaan, dan (3) saran pengembangan lebih lanjut yaitu LKPD interaktif berbasis REACT sebaiknya dapat dikembangkan untuk materi-materi yang lain, tidak hanya materi pecahan saja. Selain itu, LKPD interaktif berbasis REACT dapat diujicobakan kepada subjek yang lebih luas. Pengembang selanjutnya harus mengembangkan produk LKPD yang disesuaikan dengan situasi dan kondisi subjek yang dituju agar mudah digunakan oleh semua peserta didik baik dengan kemampuan cepat, sedang, maupun lambat dalam memahami pelajaran. Kemudian melakukan validasi produk kepada ahli materi, ahli media, maupun praktisi lapangan untuk menguji kelayakan dan keefektifan produk sebelum digunakan.

\section{Daftar Rujukan}

Daryanto. (2010). Media Pembelajaran, Peranannya Sangat Penting dalam Mencapai Tujuan Pembelajaran. Yogyakarta: Gava Media.

Depdiknas. (2004). Lembar Kerja Peserta didik. Jakarta: Departemen Pendidikan Nasional.

Depdiknas. (2006). Pedoman Memilih dan Menyusun Bahan Ajar. Jakarta: Direktorat Jendral Manajemen Pendidikan Dasar dan Menengah.

Depdiknas. (2008). Panduan Pengembangan Bahan Ajar. Jakarta: Depdiknas.

Intani, T. R., \& Hartono. (2015). Pengembangan LKS Berbasis REACT untuk Meningkatkan Kemampuan Memecahkan Masalah Peserta didik Kelas VII SMP. Unnes Physics Educational Journal. 4(2), 13.

Majid, Abdul. (2012). Perencanaan Pembelajaran Mengembangkan Standar Kompetensi Guru. Bandung: PT Remaja Rosdakarya.

Rohaeti, E., Lfx, E. W., \& Padmaningrum, R. T. (2009). Pengembangan lembar kerja siswa (LKS) mata pelajaran sains kimia untuk SMP. Jurnal Inovasi Pendidikan, 10(1).

Sadiman, A. S. (2007). Media Pendidikan. Jakarta: PT. Raja Grafindo Persada. 
Jurnal Pembelajaran, Bimbingan, dan Pengelolaan Pendidikan, 1(10), 2021, 847-854

Smaldino, S. E., Lowther, D. L., \& Russel, J.D. (2011). Teknologi Pembelajaran dan Media untuk Belajar. (Alih Bahasa: Arif Rahman). Jakarta: Kencana.

Sudjana. (2007). Media Pengajaran. Jakarta: Sinar Baru Algesindo.

Sutopo, A. H. (2003). Multimedia Interaktif dengan Flash. Yogyakarta: PT. Graha Ilmu.

Yuniawatika. (2011). Penerapan Pembelajaran Matematika dengan Strategi REACT untuk Meningkatkan Kemampuan Koneksi dan Representasi Matematik Peserta didik Sekolah Dasar. Jurnal Universitas Pendidikan Indonesia. Edisi 1. 108-109. Dari http://jurnal.upi.edu.

Yuniawatika, \& Nuraeni, N. L. S. (2016). Pengaruh Pembelajaran Strategi React terhadap Peningkatan Kemampuan Mahapeserta didik PGSD tentang Koneksi Matematis. Jurnal Ilmu Pendidikan. 1(2). 101102. 